\section{Utilization of}

\section{the Major Plant Communities in the Similkameen Valley, British Columbia ${ }^{1}$}

\author{
A. MCLEAN, T. M. LORD, AND A. J. GREEN
}

Plant Ecologist and Pedologists, Canada Department of Agriculture, Research Stations, Kamloops and Vancouver, B.C., Canada.

\section{Highlight}

The plant communities of the ponderosa pine zone in southern British Columbia offer best returns from grazing by domestic and wild ungulates. The communities of the douglasfir zone should usually be considered integrated-use areas, having significant values for both grazing and timber production. The subalpine fir zone has its main value for timber production although grazing values usually persist for many years in the lower part of the zone after logging or burning. However, the upper part of the above zone is suited mainly for grazing. Although the alpine tundra has very limited forage production it sometimes provides summer range for bighorn sheep. Since the climate is usually favorable below 3000 feet elevation, arable agriculture should be considered where soils are not restrictive.

An ecological study was made of the Similkameen River drainage in order to provide basic information for use in land management. The area lies in southern British Columbia west of the Okanagan Valley and adjacent to the United States border.

Information gathered attempted to reflect the biotic capabilities of the environment so that the results could be used for as many productive uses as possible. Evaluation of the habitat types for recreation and wildlife was beyond the scope of the present study, however, except in a general way.

The approach of the investigation was to describe the habitat types based on vegetation, relate them as much as possible to environmental factors especially soils, and estimate their value for grazing and forestry. Some significant relationships between soils, vegetation, and physiographic units as revealed through aerial photo patterns have already been reported (Lord and McLean, 1969).

The tcrm "habitat typc" is uscd to include sites that have the potentiality of supporting a single type of climax association but are not necessarily in climax condition at the present time (Daubenmire, 1968).

The plant community classification used is that of McLean (1969). Plant nomenclature follows Hitchcock et al. $(1955,1959,1961,1964)$ for dicotyledons and Davis (1955) for all other plants. Soils nomenclature follows the Canadian System (Soil Survey Committee of Canada, 1968).

The ponderosa pine and douglasfir zones, inter-

${ }^{1}$ Received August 24, 1970. spersed with open grasslands, occupy the lower elevations in the Similkameen Valley while the subalpine fir zone, now mostly covered by stands of lodgepole pine (Pinus contorta) occupies the higher elevations to upper treeline. Isolated areas of alpine tundra are found on some mountain tops (Fig. 1).

Fire and logging in the forests and livestock grazing and pocket gopher activity on the grasslands have been the most common factors disturbing the vegetation in the study region, often causing abrupt changes in the pattern.

\section{Ponderosa Pine Habitat Types}

The ponderosa pine zone occupies the lower slopes and outwash terraces in the valley, generally from about 2000 to 2700 feet elevation. It is relatively dry and ponderosa pine (Pinus ponderosa) forms open stands when mature. Only one major habitat type occupies this zone (McI ean, 1969).

\section{Ponderosa pine-Idaho fescue}

In a climax or near-climax state ponderosa pine is the sole dominant tree while the ground cover is dominated by bluebunch wheatgrass (Agropyron spicatum) and Idaho fescue (Festuca idahoensis) (Fig. 2). A wide variety of herbs normally occurs as well. The absence of shrubs in this community is notable.

Soils associated with this habitat typc are mostly well drained, moderately coarse textured Orthic Dark Grays developed on glaciofluvial deposits.

Differences in vegetation resulting from different grazing management on opposite sides of a fenceline indicate that bluebunch wheatgrass and Idaho fescue are less abundant on grazed areas. Silky lupine (Lupinus sericeus) appears to decrease with spring or early summer grazing. The outstanding perennial species that increase with heavy grazing are Sandberg's bluegrass (Poa secunda), low pussytoes (Atennaria dimorpha), and shaggy fleabane (Erigeron pumilus). The most characteristic annual species that invade are cheatgrass (Bromus tectorum), sixweeks fescue (Festuca octoflora), and stickseed (Lappula redowskii).

Stands in excellent range condition have a medium herbage yield (Table 1) where trees do not depress herbaceous growth. Most ranges are at present producing much less than maximum because of past heavy grazing and damage by pocket gophers. Because of the relatively dry climate and variations in soil moisture holding capacity, considerable variation is found from site to site.

Stands of this community are classed as lowmedium for the production of ponderosa pine (Table 2). One stand which was stocked at the rate of 388 trees (dominant height 65 feet, age 70 years) per acre produced $82 \%$ of the herbage yield of an adjacent cleared area. At the above stocking rate 


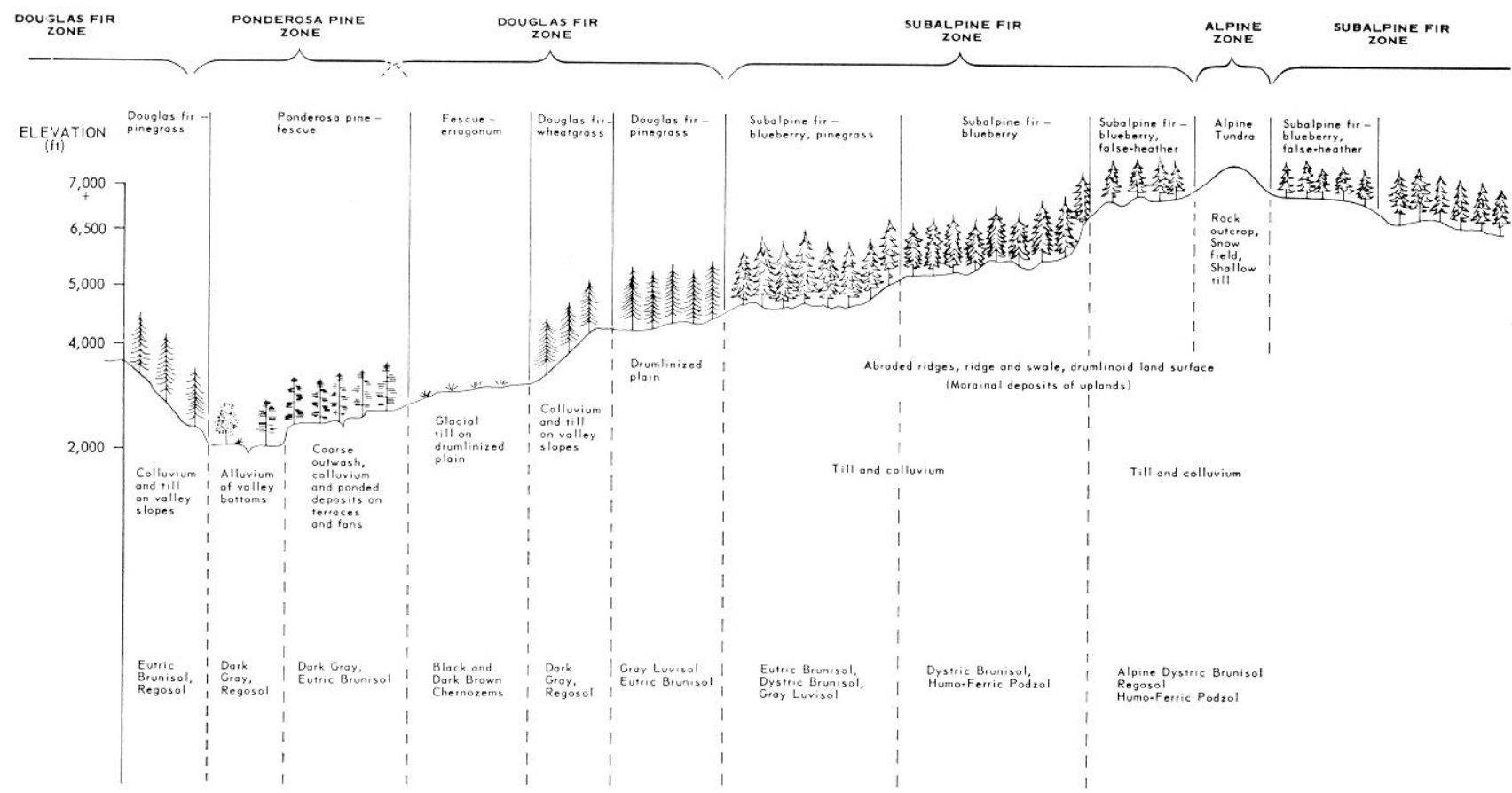

FIG. 1. The relationship between elevation, plant zone, habitat type, soil parent material, and great group of soil in the Similkameen Valley.

the presence of trees did not seriously reduce the forage production.

The ponderosa pine-fescue community is well suited for spring and fall grazing which is in critical supply in the region. Irrigation is necessary for crop production.

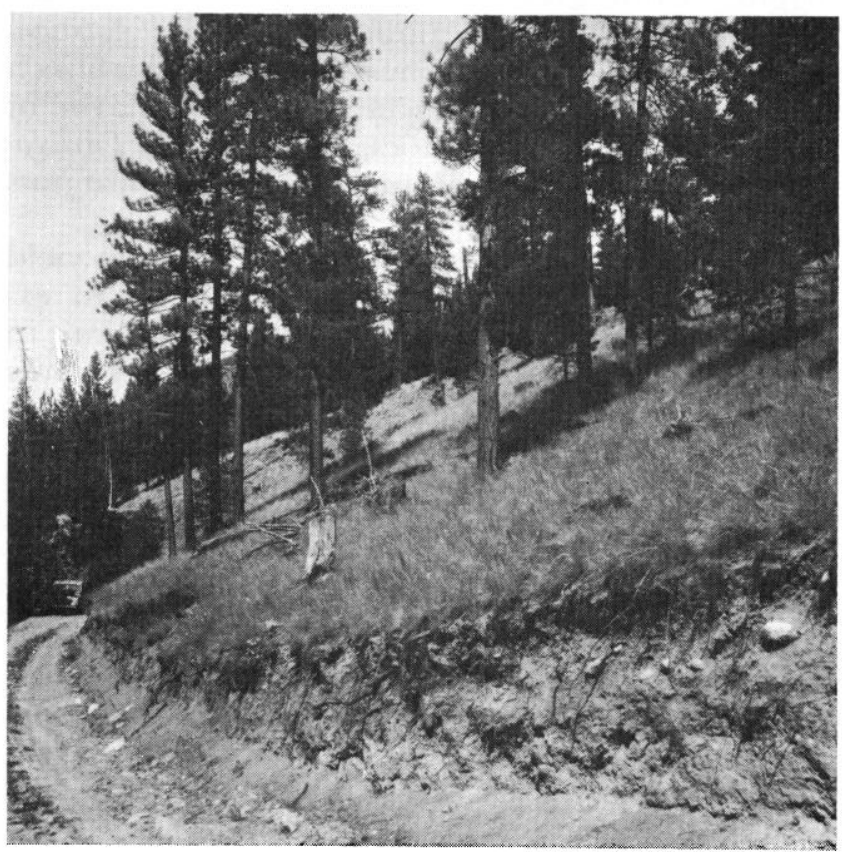

FIG. 2. Ponderosa pine-Idaho fescue community in near-climax condition in the Similkameen Valley. The ground cover is dominated by Idaho fescue and bluebunch wheatgrass.
After deforestation, a grassy undergowth persists for a long time since re-establishment of the forest is usually very slow. Deforestation has usually been the result of a combination of logging and fire or clearing for cultivation so that tree destruction was complete and seed trees are rare. Small trees were often cut for fence posts or destroyed during cultivation. Heavy grazing has retarded tree reestablishment since reproduction is readily grazed when grasses are dormant and of low quality.

Gophers often become a serious problem in this habitat type, frequently destroying the greater part of the perennial herbaceous vegetation thus encouraging the growth of annuals and hindering efforts in range rehabilitation. Seeding to crested wheatgrass (Apropyron desertorum) may be considered for range improvement where soil and topography permit.

Table 1. Herbage yield (1b./acre oven dry, five-year average) from plots clipped on selected climax plant communities in the Similkameen Valley.

\begin{tabular}{lccc}
\hline \hline \multicolumn{1}{c}{ Plant community } & Yield & Yield class $^{1}$ & $\begin{array}{c}\text { No. of } \\
\text { sites }\end{array}$ \\
\hline Ponderosa pine-Idaho fescue & 700 & medium & 12 \\
Douglasfir-bluebunch wheatgrass & 400 & low & 5 \\
Douglasfir-Idaho fescue & 800 & medium & 9 \\
Douglasfir-pinegrass & 600 & low-medium & 8 \\
Idaho fescue-eriogonum & 1,600 & high & 2 \\
\hline
\end{tabular}

${ }^{1}$ Below 500 1b./acre, low; 500 to 750 , low-medium; 750 to 1,000 , medium; 1,000 to 1,500, medium-high; above 1,500, high. 
Table 2. Average site indexes (100 years) and site classes for trees in selected plant communities in the Similkameen Valley.

\begin{tabular}{|c|c|c|c|c|c|c|c|c|c|c|}
\hline \multirow[b]{2}{*}{ Plant communities } & \multicolumn{2}{|c|}{ Ponderosa pine } & \multicolumn{2}{|c|}{ Douglasfir } & \multicolumn{2}{|c|}{ Lodgepole pine } & \multicolumn{2}{|c|}{$\begin{array}{c}\text { Engelmann } \\
\text { spruce }\end{array}$} & \multicolumn{2}{|c|}{ Subalpine fir } \\
\hline & Index & Class & Index & Class & Index & Class & Index & Class & Index & Class \\
\hline Douglasfir-bluebunch wheatgrass & 50 & poor & 55 & poor & - & - & - & - & - & - \\
\hline Ponderosa pine-Idaho fescue & 65 & medium & 65 & poor & - & - & - & - & - & - \\
\hline Douglasfir-Idaho fescue & 75 & medium & 75 & medium & - & - & - & - & - & - \\
\hline Douglasfir-pinegrass & 80 & medium & 75 & medium & 65 & medium & - & - & - & - \\
\hline Subalpinc fir-bluebcrry, pincgrass & - & - & 65 & poor & 70 & medium & - & - & - & - \\
\hline Subalpine fir-red alpine blueberry & - & - & 80 & medium & 85 & good & 100 & good & 75 & medium \\
\hline Subalpine fir-blueberry, false-heather & - & - & - & - & 65 & medium & 55 & poor & 50 & poor \\
\hline
\end{tabular}

Recovery of the range from overgrazing in this community is slow. For example, on one stony, Orthic Dark Gray soil a fenced area has been under complete protection from grazing by domestic animals since 1937. In that time although the cover of bluebunch wheatgrass has increased from 1 to $20 \%$ the stand is in only fair range condition. Clipping over four years indicates that the herbage yield inside the fence is about $30 \%$ greater than that of the grazed area outside.

\section{Douglasfir Habitat Types}

The douglasfir zone lies between the open savannah-like forest of the ponderosa pine zone and the dense forest of the subalpine fir zone. It is principal forest-grazing type in British Columbia (Tisdale and McLean, 1947). Most of the habitat types within the zone produce a moderately dense forest and yield a significant volume of forage.

\section{Douglasfir-bluebunch wheatgrass}

The douglasfir-wheatgrass community occurs locally, largely in the eastern part of the area as a topoedaphic climax, mostly on steep southeast and west facing slopes. The characteristic tree is douglasfir (Pseudotsuga menziesii). Ponderosa pine may or may not be present. Bluebunch wheatgrass dominates the ground cover and pinegrass (Calamagrostis rubescens) and Idaho fescue are generally absent.

The soils are Orthic Regosols and Orthic Dark Grays which are rubbly, eroded, and contain a high percentage of coarse material. Where downhill underground water movement is a factor the soils may be calcareous to the surface.

Grazing is often light because of surface, angular rocks which cause unstable footing for the cattle. Because of the degree of slope, exposure, and nature of the soil, herbage production on this habitat type is low (Table 1 ).

The habitat type is generally poor for growth of douglasfir except where sub-soil moisture is a factor.

One plot with 324 trees (dominant height 50 feet, age 100 years) per acre produced an herbage yield over five years that was $55 \%$ of that on a similar adjacent cleared area.

\section{Douglasfir-Idaho fescue}

This habitat type is found in the lower part of the douglasfir zone. It closely resembles the ponderosa pine-Idaho fescue community although it contains fewer characteristic species. Most stands are at present dominated by ponderosa pine. Characteristic ground-cover species are mostly those of the grasslands cxcept that pinegrass is present above 2000 feet elevation. The proportion of shrubs is very low.

The soils are well drained and moderately coarse textured Orthic Dark Grays and Orthic Degraded Eutric Brunisols developcd on coarse textured glaciofluvial deposits and moderately coarse textured till.

Pinegrass usually decreases in abundance after logging, while grassland species such as Junegrass (Koeleria cristata) and timber milkvetch (Astragalus miser) increase. With heavy grazing, bluebunch wheatgrass and Idaho fescue decrease in favor of the needlegrasses, pussytoes, dandelion (Taraxacum officinale), and annuals such as cheatgrass and stickseed.

This plant community produces a medium yield (Table 1) of high quality herbage when in excellent range condition. Most of the ranges are in less than good condition moderately dense tree stands so that the present carrying capacity is considerably less. One site which was stocked at the rate of 260 trees (dominant height 70 feet, age 90 years) per acre produced only $45 \%$ of the total herbage yield as compared with an adjacent, apparently similar, cleared area.

This habitat type was medium for the production of both douglasfir and ponderosa pine (Table 2) with an average sit index of 75 for both species. Regeneration is usually slow because of soil drought. Many areas are suitable for Christmas tree production.

This community is suited to integrated use; the trees being managed for ponderosa pine or douglasfir and grazing being moderate early-summer use. 


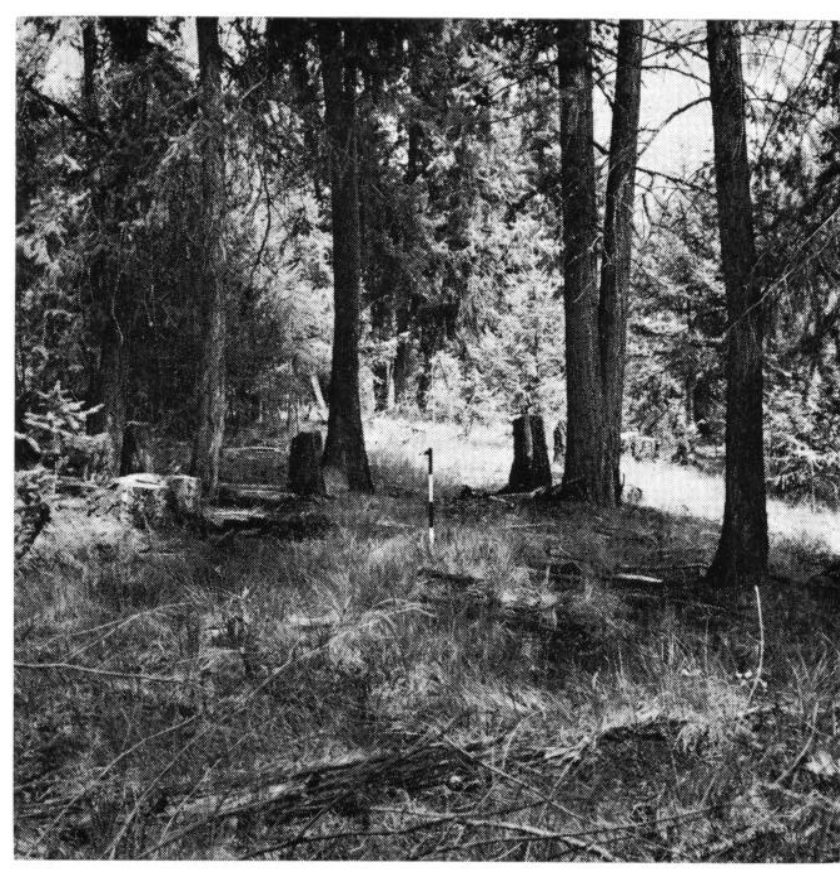

FIg. 3. Douglasfir-pinegrass community in the Similkameen Valley following selective logging. The ground cover is dominated by pinegrass.

The type is found at sufficiently low elevations that arable agriculture and irrigation may sometimes be considered. Range rehabilitation by rest-rotation grazing or seeding to crested wheatgrass and smooth bromegrass (Bromus inermis) is usually successful.

\section{Douglasfir-pinegrass}

The most widespread habitat type within the douglasfir zone, and the climatic climax between 3000 and 4500 feet elevation, is dominated by douglasfir with an understory predominately of pinegrass (Fig. 3). At present, however, lodgepole pine dominates much of this community as a result of fires and logging. There is an increase in shrub cover as compared with the drier types.

The soils are well drained and moderately coarse textured Orthic Gray Luvisols (Orthic Gray Wooded) and Degraded Eutric Brunisols on moderately coarse textured glacial till.

At lower elevations there is an increase in bluebunch wheatgrass and Junegrass following logging. Kentucky bluegrass (Poa pratensis) increases on the deeper soils, especially around abandoned homesteads where grazing is usually heavy. Higher in the zone there is an increase in pinegrass, timber milk-vetch, and forest lupine (Lupinus arcticus) with disturbance. There may also be an increase in dandelion, pussytoes, and heart-leafed arnica (Arnica cordifolia).

The habitat type produces only a low-medium volume of herbage even when the tree influence has been removed (Table 1). One site from which the trees had been logged produced 37\% more herbage as compared with an adjacent plot which contained 130 trees (dominant height 86 feet, age 140 years) per acre.

When this community occurs on south-facing slopes, the winter snow-pack is less than 30 inches, and the shrub component is significant so that it often becomes prime deer winter-range.

Site indexes show a low-medium growth potential for douglasfir (70), medium for ponderosa pine (80) but poor for lodgepole pine (60).

This type is suited to summer grazing for cattle and to the harvest of douglasfir and ponderosa pine. It is well adapted to integrated use. After fires or logging, forage production may be improved relatively inexpensively by seeding to timothy (Phleum pratensis), orchard grass (Dactylis glomerata), smooth bromegrass, and white clover (Trifolium repens).

\section{Idaho fescue-eriogonum}

This community occurs as a parkland between the ponderosa pine and douglasfir zones and on a few dry, south-facing slopes at high elevation (up to 6,000 feet). Herbaceous grassland species dominate the cover except where clumps of aspen (Populus tremuloides) in depressions interrupt the habitat type. Shrubs are not conspicuous.

Soils belonging to the Orthic Black subgroup occur under grass vegetation, with Orthic Dark Brown soils on the drier positions. Orthic Dark Gray soils occur under aspen. The soils are mostly well drained, moderately coarse textured and developed on till and colluvium.

Although Idaho fescue and bluebunch wheatgrass dominate stands in near-climax condition, Kentucky bluegrass has often replaced these species on the deeper soils. Columbia needlegrass (Stipa columbiana) and needleandthread (Stipa comata) have taken over on the drier sites as a result of grazing pressure. Under severe disturbance cheatgrass is a vigorous invader along with many other annuals.

These grasslands are the most productive of native herbage in the region (Table 1) but vary greatly depending on depth and moisture-holding capacity of the soil.

This type makes excellent spring and fall range. The current productivity of most of it is much less than maximum because of heavy grazing in the past and widespread damage caused by pocket gophers which have increased with the removal of coyotes. Grazing into early summer or season long is particularly damaging to the preferred species.

This community usually recovers fairly quickly from disturbance by resting from grazing, or practising deferred rotation. In reseeding, a number of species may be used, such as crested wheatgrass, intermediate wheatgrass (Agropyron intermedium), smooth bromegrass, and alfalfa (Medicago sativa). 


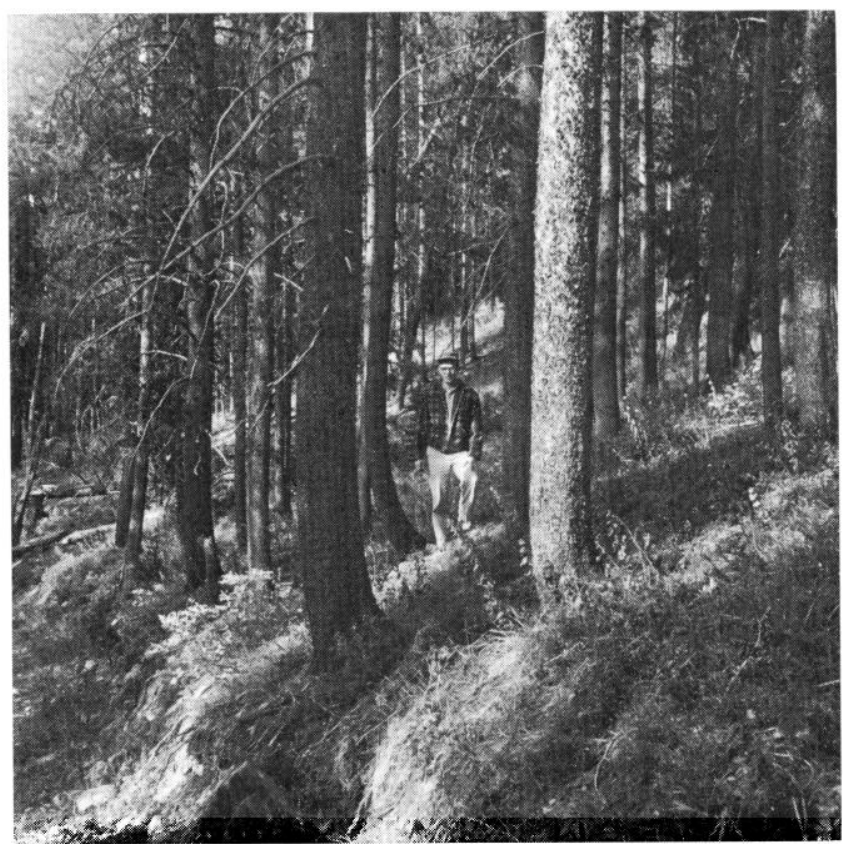

FIg. 4. Subalpine fir-red alpine blueberry habitat type, pinegrass phase currently dominated by lodgepole pine in the Similkameen Valley. The ground cover is dominated by pinegrass and red alpine blueberry.

\section{Subalpine Fir Habitat Types}

The subalpine fir zone lies between the douglasfir and the alpine zones. Although subalpine fir (Abies lasiocarpa) is the climax tree nearly all stands are dominated by engelmann spruce (Picea engelmanni) or lodgepole pine (McLean, 1969).

\section{Subalpine fir-red alpine}

blueberry, pinegrass phase

This habitat type is widespread on relatively dry sites especially in the lower part of the zone. Nearly all stands are currently dominated by lodgepole pine (Fig. 4). The ground cover is dominated by red alpine blueberry (Vaccinium scoparium) and pinegrass.

The community is found on well drained, moderately coarse textured glaciofluvial deposits and on shallow till over bedrock. It also occurs in transitional areas between Orthic Dystric and Orthic Eutric Brunisols which have developed on till and colluvium.

This community has only a "fair" rating for forage productivity since most sites are free of trees for only about ten years after fires or logging and movement of cattle is impeded. Grazing values can be enhanced after logging by seeding to grass. Seeding, however, should be done as soon as possible after logging or burning. Open stands of lodgepole pine, however, produce a moderate volume of medium quality forage, mostly pinegrass.

The habitat type is poor for the growth of sub- alpine fir, and douglasfir and medium for spruce and lodgepole pine (Table 2). The importance of slope position can be illustrated by one site with three slope positions. Lodgepole pine on the site at the top of the slope had an index of 65 , in the middle position an index of 70 and in the toe position an index of 90 . Because of a relatively short cutting cycle the type is probably best suited to lodgepole pine management. Clear cutting, burning, and seeding to grass should be considered to provide additional grazing for a period of years before the tree reproduction closes in.

\section{Subalpine fir-red alpine blueberry}

Although this habitat type forms the climatic climax within the zone it is not so well represented in the study area as in adjacent Washington. Rather, the two phases mentioned herein occupy most of the zone. Subalpine fir is the climax tree but most stands at present are dominated by engelmann spruce, douglasfir, or lodgepole pine, with an understory of subalpine fir. Shrubs, the most common of which is red alpine blueberry, are abundant in the ground cover.

The soils associated with this community are usually well drained, moderately coarse textured Mini Humo Ferric Podzols and Degraded Dystric Brunisols developed on coarse textured colluvial and till deposits.

Because of the usually dense stands of trees, light is sufficiently restricted so as to keep forage production to a minimum except for a few years after logging when the values are high. Shrubs are an important component of cleared areas but are more important as feed for moose and deer than for cattle.

The type normally produces a dense forest and has good value for timber, especially the production of spruce and lodgepole pine (Table 2).

\section{Subalpine fir-red alpine blueberry, false-heather phase}

This phase of the subalpine fir-red alpine blueberry habitat type occurs as the climatic climax in the upper part of the subalpine fir zone. Engelmann spruce and subalpine fir are the dominant trees although many stands are at present dominated by lodgepole pine. False-heathers (Phyllodoce empetriformis and P. glanduliflora) are normally present in the ground cover. There are many grassy openings in this type in whose formation fire seems to have played an important role and in which re-invasion of trees is very slow.

The community is found on well drained, moderately coarse textured Orthic Alpine Dystric Brunisols developed on materials that include till, colluvium, and aeolian deposits. In association with these soils are Orthic Humo Ferric Podzols under forest cover on north-facing slopes. 


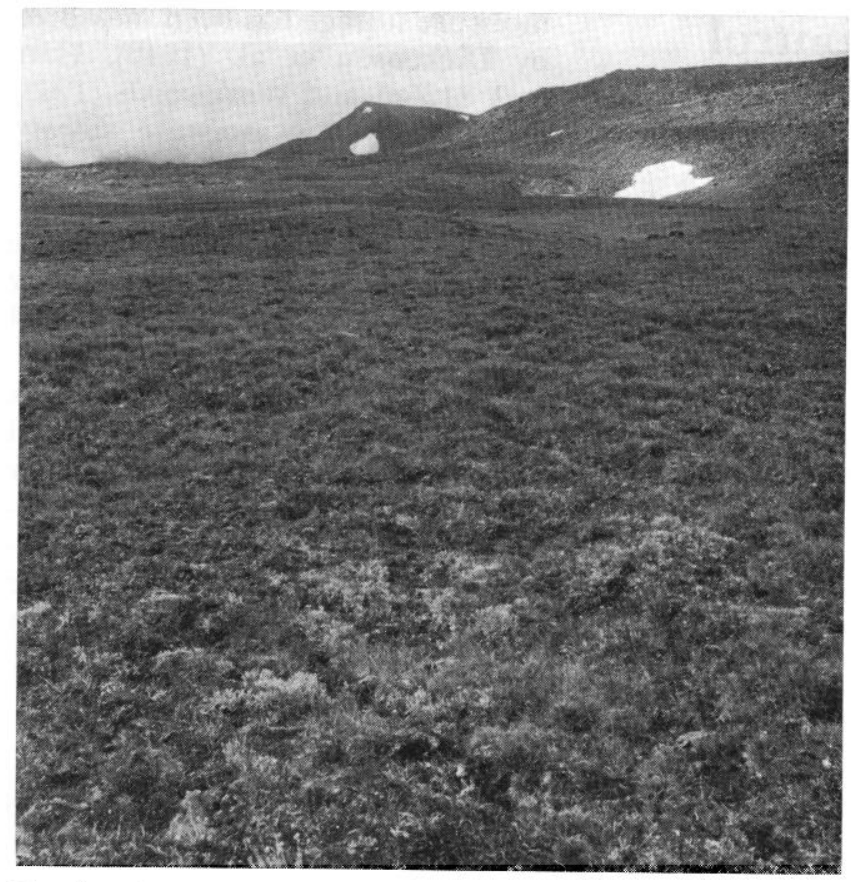

FIG. 5. Alpine tundra in the Similkameen Valley. The ground cover is a mixture of alpine grasses, dryland sedges and forbs.

This community has value for mid-summer grazing by domestic and wild ungulates but is often unproductive except in draws and protected locations where extra moisture from snow drifts accumulates. Herbage yield varies greatly but a reasonable average would be about $300 \mathrm{lb}$. of total forage per acre.

The forest is unproductive. Most trees are sharply tapered and the site indexes for spruce and subalpine fir are low (Table 2).

Because of the usually attractive physiogonomy, this habitat type often has potential for recreation.

\section{Alpine Zone}

This zone lies above timberline (Fig. 5). The climate is cold and the growing season is short. Most of the slopes are dry and windswept, supporting a mixture of low-growing (often less than 6 inches) alpine grasses, dryland sedges, and forbs.

On disturbed sites dryas (Dryas octopetala), dwarf lupine (Lupinus lepidus var. lobbii), and snow willows (Salix nivalis, S. cascadensis) invade quickly.

Because of the cold climate and short growing season, the vegetation is unproductive and provides only limited grazing for cattle. It is well suited as summer range for bighorn sheep where these animals occur. On upland sites total annual herbage production seldom exceeds $200 \mathrm{lb}$./acre, much of which is unavailable except under very close cropping.

The soils are well drained and moderately coarse textured Lithic Alpine Dystric Brunisols developed on coarse textured undivided materials that in- clude volcanic ash, colluvium, and till deposits which are shallow over bedrock. Coarse textured Orthic and Cumulic Regosols occur at the base of snow banks and in areas disturbed by solifluction.

\section{Summary}

From a land use standpoint the following habitat types are suitable primarily for grazing: Idaho fescue-eriogonum on Black, Dark Gray and Dark Brown soils; ponderosa pine-bluebunch wheatgrass on Dark Gray soils; douglasfir-bluebunch wheatgrass on Dark Gray and Regosolic soils; and subalpine fir-red alpine blueberry, false-heather phase on Alpine Dystric Brunisols.

The douglasfir-Idaho fescue and douglasfir-pinegrass communities should be considered integrateduse areas, except under exceptional circumstances, yielding about 800 and $600 \mathrm{lb}$./acre of forage respectively and having an average site index for ponderosa pine and douglasfir of 75 for timber.

On integrated-use areas, biomass production from any single use is generally not sufficient to justify intensive management, such as tree thinning, to improve timber production and temporarily increase forage yields for domestic and wild ungulates. If, however, such costs could be shared by a number of land users and result in a greater biomass production, more intensive management would be justified in many cases.

The subalpine fir-red alpine blueberry-pinegrass habitat type usually has considerable value for grazing for at least 15 years after logging and fires. The subalpine fir-red alpine blueberry is suited primarily for the production of spruce, lodgepole pine, and douglasfir.

Since the climate is usually favorable below 3,000 feet elevation, arable agriculture, including irrigation, should be considered where slope, and stoniness are not restrictive factors.

\section{Literature Cited}

Daubenmire, R. 1968. Plant communities. Harper \& Row, New York. 300 p.

DAvis, R. J. 1955. Flora of Idaho. W. C. Brown, Dubuque, Iowa. 828 p.

Hitchcock, C. L., Arthur Cronguist, Marion Ownby, and J. W. Thompson. 1955, 1959, 1961, 1964. Vascular plants of the Pacific Northwest. Univ. of Washington Press, Seattle. 4 vol.

Lord, T. M., and Alastair McLean. 1969. Aerial photo interpretation on British Columbia rangelands. J. Range Manage. 22:3-9.

Mclean, Alastair. 1969. Plant communities of the Similkameen Valley, British Columbia and their relationships to soils. Ph.D. Thesis. Washington State Univ. $133 \mathrm{p}$.

Soll Survey Committee of Canada. 1968. Proc. Seventh Nat. Meeting. Can. Dep. Agr. Ottawa. 215 p.

Tisdale, E. W., and A. McLean. 1957. The douglas-fir zone of southern interior British Columbia. Ecol. Monogr. 27:247-266. 